\title{
The role of genetics in the variable clinical response to different forms of malaria
}

\author{
David Weatherall \\ From Challanges in malaria research: Core science and innovation \\ Oxford, UK. 22-24 September 2014
}

There is now strong evidence that variable degrees of protection against infection with $P$. falciparum malaria is mediated by the carrier state for a variety of different inherited disorders of haemoglobin, genetic variation in the red blood cell membrane or metabolism, and a variety of different blood groups. Similarly, genetic factors are also involved in either increasing or decreasing the susceptibility to $P$. vivax malaria. Recent work has shown that there are some remarkable epistatic interactions between the different genes involved in these conditions and the resulting susceptibility to different forms of malaria. These new findings, combined with further information obtained about the genetic basis of malaria resistance based on genome-wide association studies are already leading to a better understanding of the mechanisms whereby some of these genetic disorders offer protection to different forms of malaria, the mechanism of which is still ill-understood. In addition, these new approaches are starting to provide invaluable information about the remarkably heterogeneous distribution of some of these genetic variants, notably the inherited haemoglobin disorders.

Published: 22 September 2014

Submit your next manuscript to BioMed Central and take full advantage of:

- Convenient online submission

- Thorough peer review

- No space constraints or color figure charges

- Immediate publication on acceptance

- Inclusion in PubMed, CAS, Scopus and Google Scholar

- Research which is freely available for redistribution 